\title{
Faktor Pendidikan dan Kesehatan Berpengaruh Terhadap Kemiskinan di Provinsi Jambi
}

\section{Oleh:}

\author{
*) Ali Fahmi, S.E., M.Si. \\ **) Dosen Tetap STIE Muhahammadiyah Jambi
}

\begin{abstract}
Abstrak
Tujuan dari penelitian ini adalah untuk mengetahui pengaruh dari variabel Tingkat Pendidikan, Kesehatan terhadap Kemiskinan di Provinsi Jamb itahun 2004-2014. Pemilihan variabel tingkat pendidikan dan kesehatan karena kedua variabel ini merupakan investasi SDM untuk meningkatkan produktivitas seseorang. Dimana dengan tingginya angka produktivitas maka gaji yang diperoleh juga akan meningkat dan kesejahteraan tercapai. Penelitian ini adalah penelitian kuantitatif deskriptif dengan data timeseries. Setelah dilakukan ujia sumsi klasik, baru dilanjutkan dengan teknik analisis regresi linear berganda untuk mengetahui besarnya pengaruh masing-masing variabel terhadap tingkat kemiskinan. Hasil dari penelitian ini menunjukkan bahwa kedua variabel bebas berpengaruh terhadap tingkat kemiskinan. Secara parsial Tingkat pendidikan tidak signifikan sedangkan tingkat Penkesehatan secara parsial signifikan
\end{abstract}

Kata Kunci: Tingkat Pendidikan, Kesehatan, Tingkat Kemiskinan, Regresi Linear Berganda

\section{Pendahuluan}

Pembangunan bidang pendidikan dan kesehatan merupakan dua pilar untuk membentuk modal manusia (humancapital) dalam pembangunan ekonomi yang tidak lain adalah investasi jangka panjang suatunegara. Tercapainya tujuan pembangunan bidang pendidikan dan kesehatan, pada gilirannya dapat meningkatkan kualitas dan produktivitas penduduk, dimana pertumbuhan produktivitas penduduk tersebut merupakan motor penggerak pertumbuhan ekonomi dan kesejahteraan.

Pendapat Todaro (2003) ada tiga nilai pokok dalam keberhasilan pembangunan ekonomi; kecukupan (sustenance), jati diri (selfsteem), serta kebebasan (freedom).

Melalui investasi pendidikan akan mampu meningkatkan kualitas sumber daya manusia yang diperlihatkan oleh meningkatnya pengetahuan dan ketrampilan yang akan mendorong peningkatan produktivitas kerja seseorang, dan pada akhirnya seseorang yang memiliki produktivitas tinggi akan memperoleh kesejahteraan yang lebih baik dan terhindar dari kemiskinan.

Salah satu tujuan pembangunan nasional adalah meningkatkan perekonomian agar mampu menciptakan lapangan kerja dan menata kehidupan yang layak bagi seluruh rakyat, 
yang ada pada gilirannya akan mewujudkan kesejahteraan masyarakat dan menurunkan tingkat kemiskinan.

Kemiskinan adalah suatu kenyataan yang belum dan terhapuskan dari muka bumi ini. Kemiskinan timbul akibat perbedaan kemampuan, perbedaan kesempatan, dan perbedaan sumberdaya.

Chambers mengatakan bahwa kemiskinan adalah suatu intergrated concept yang memiliki lima dimensi, yaitu : 1) kemiskinan (proper), 2) ketidakberdayaan (powerless), 3) kerentangan menghadapi situasi darurat (state of emergency), 4) ketergantungan (dependence), 5) ketersaingan (isolation) baik secara geografis maupun sosiologis. (Suryawati, 2005).Dalam artian istilah kemiskinan (poverty) muncul ketika seseorang atau sekelompok orang tidak mampu mencukupi tingkat kemakmuran ekonomi yang dianggap sebagai kebutuhan minimal dari standar hidup tertentu.Kemiskinan dipahami sebagai keadaan kekurangan uang dan barang untuk menjamin kelangsungan hidup.

Sedangkan Menurut World Bank (2004), penyebab kemiskinan adalah kurangnya pendapatan dan aset (lack of income and assets) untuk memenuhi kebutuhan dasar seperti makanan, pakaian, perumahan, kesehatan dan pendidikan yang dapat diterima (acceptable). Salah satu kriteria dari kemiskinan yang umum digunakan dan diterima secara luas adalah rendahnya pendapatan (Simon Kuznets). Pendapatan mencerminkan standar rill masyarakat. Standar hidup rill masyarakat menunjukkan tingkat kesejahteraan masyarakat, maka dapat dikatakan bahwa pendapatan merupakan kriteria tingkat kesejahteraan masyarakat (Adisasmita, 2013).

Akan tetapi tinggi rendahnya pendapatan masyarakat, tidak akan maksimal apabila tidak disertai dengan sumber daya manusia yang berkualitas. Dengan demikian, pembangunan kualitas sumber daya manusia harus menjadi prioritas utama bagi pemerintah. Seperti halnya pendidikan dan kesehatan.

Disamping faktor pendapatan aspek pendidikan dan kesehatan mempunyai pengaruh terhadap tingkat kesejahteraan masyakarat. Hal ini dinyatakan oleh Todaro (1997) bahwa sebagian besar masyarakat di negara berkembang mempunyai standar hidup (levels of living) yang rendah.

Standar hidup yang rendah ini menurut Todaro (1997) dan Arsyad (1999) dimanifestasikan dalam bentuk jumlah pendapatan uang yang sedikit (miskin) perumahan yang kurang layak, kesehatan yang buruk, bekal pendidikan yang minim, angka kematian 
bayi yang tinggi, angka harapan hidup yang relatif singkat dan peluang untuk mendapatkan pekerjaan yang rendah. Dengan demikian secara umum dapat dikatakan bahwa standar hidup masyarakat di negara berkembang yang rendah dipengaruhi oleh faktor pendapatan, pendidikan, dan kesehatan.

Berdasarkan studi Nasikun pada tahun 1987 yang terdapat pada Sairin, Efenddi dan Dahlan (1992) menemukan bahwa status kesehatan dan gizi pekerja berpengaruh terhadap produktifitas masyarakat. Dalam hal ini tercermin daya tahan tubuhnya untuk melakukan pekerjaan secara efektif dan efisien.

Kekurangan makanan sehat gizi dan berpenyakit, bukan hanya memberikan pengaruh yang tidak baik terhadap kemampuan anak seperti membaca, menulis, menyelesaikan hitungan, dan berpikir cerdas dan logis di sekolah (kemampuan kognitif), Todaro (1997) juga menyatakan bahwa hal itu akan memberikan pengaruh yang tidak baik terhadap kesempatan memperoleh atau melaksanakan pekerjaan (status jabatan) dan merendahkan produktifitasnya serta prestasi umum dalam pekerjaan.

Tercapainya tujuan pembangunan bidang pendidikan dan kesehatan, pada gilirannya dapat meningkatkan kualitas dan produktivitas penduduk, dimana pertumbuhan produktivitas penduduk tersebut merupakan motor penggerak (engine of growth) pertumbuhan ekonomi dan kesejahteraan penduduk itu sendiri. Melalui investasi pendidikan akan mampu meningkatkan kualitas sumberdaya manusia yang diperlihatkan oleh meningkatnya pengetahuan dan keterampilan yang akan mendorong peningkatan produktivitas kerja seseorang, dan pada akhirnya seseorang yang memiliki produktivitas yang tinggi akan memperoleh kesejahteraan yang lebih baik dan terhindar dari kemiskinan.

Selain perbaikan dan tingkat pendidikan, perbaikan pada tingkat kesehatan juga perlu dilakukan karena pada dasarnya kesehatan merupakan suatu investasi sumber daya manusia untuk mencapai masyarakat yang sejahtera (welfare society). Tingkat kesehatan masyarakat yang ditunjukkan oleh Angka Harapan Hidup (AHH) sebagai indikatornya akan sangat berpengaruh terhadap tingkat kesejahteraan masyarakat dan memiliki keterkaitan yang erat dengan kemisikinan. Sementara itu, tingkat kemiskinan akan terkait dengan tingkat kesejahteraan. Oleh karena itu, kesehatan merupakan faktor utama dalam upaya meningkatkan kesejahteraan masyarakat, maka kesehatan selalu menjadi perhatian utama pemerintah sebagai penyelenggara pelayan publik. Pemerintah harus dapat menjamin hak 
masyarkat untuk sehat dengan memberikan pelayanan kesehatan secara adil, merata, memadai, terjangkau dan berkualitas.

Permasalahan pemerintah Provinsi Jambi tidak jauh berbeda dengan pemerintah pusat, yakni tingkat kemiskinan yang relatif masih tinggi. Oleh karena itu, kemiskinan menjadi tanggung jawab bersama, terutama pemerintah sebagai penyangga proses perbaikan kehidupan masyarakat dalam pemerintahan.

Persentase penduduk miskin di Provinsi Jambi periode 2004-2014 mengalami fluktuasi dimana rata-rata persentase penduduk miskin di Provinsi Jambi periode 2004-2014 yaitu 9,58 persen pertahun dengan perkembangan menurun sebesar 3,49 persen pertahun. Fluktuasinya angka kemiskinan di Propinsi Jambi dipicu naiknya harga BBM sehingga menyebabkan Inflasi.

Pembangunan kualitas sumber daya manusia di Provinsi Jambi dalam penelitian ini dilihat dari Rata-rata Lama Sekolah (RLS). RLS merupakan salah satu indikator yang digunakan dalam pencapaian pembangunan sumber daya manusia, karena semakin lama atau semakin tinggi tingkat pendidikan seseorang, maka ilmu dan pengetahuan yang akan diperoleh juga akan semakin bertambah begitu juga sebaliknya.

Secara umum kondisi pendidikan di Provinsi Jambi jika di lihat dari RLS periode 2004-2014 menunjukkan peningkatan dari tahun ke tahun dan pada tahun akhir 2014 Rata Lama Sekolah menunjukkan peningkatan yaitu 8,5 tahun dengan perkembangan 2,41 persen yang artinya pendidikan dijalani 8,5 tahun. Itu artinya tingkat pendidikan rata-rata masyarakat Provinsi Jambi masih berada padakelas 2 semester 1SMP.Dan rata-rata pertahun masyarakat Provinsi Jambi menjalani pendidikan 7,84 pertahun atau 1,27 persen.

Dalam hal kesehatan yang dilihat dari Angka Harapan Hidup (AHH) Provinsi Jambi yang mana AHH merupakan salah satu indikator atau tolak ukur yang dapat digunakan dalam mengukur tingkat kesejahteraan masyarakat khususnya masyarakat di Provinsi Jambi.

Pada tahun 2004 Angka Harapan Hidup di Provinsi Jambi sebesar 67,6 tahunrata-rata perkiraan hidup 70 tahun.

\section{Tujuan Penelitian}

Tujuan penelitian ini adalah : menemukan bukti empiris mengenai pengaruh tingkat pendidikan, kesehatan terhadap tingkat kemiskinan di Provinsi Jambi. 


\section{Metode Penelitian}

Jenis Penelitian yang dilakukan adalah kualitatif kausalitas. Penelitian ini untuk menguji pengaruh Pendidikan, kesehatan terhadap tingkat kemisikinan di Provinsi Jambi.

Data yang digunakan dalam penelitian ini adalah data sekunder yang diperoleh dari Jambi Dalam Angka (JDA) terbitan Badan Pusat Statistik (BPS) Jambi. Adapun data yang digunakan adalah data kurun waktu (time series) dari Tahun 2004-2014

Berikut Untuk memudahkan pemahaman terhadap penelitian ini dengan definisi operasioanal variabel yang digunakansebagai berikut :

a. Tingkat kemiskinan (Y) tingkat kemiskinan dalam penelitian ini menggunakan ukuran kemiskinan yang telah ditetapkan oleh Badan Pusat Statistik (BPS). Yaitu; persentasependuduk miskindi Provinsi Jambi periode 2004-2014.

b. Tingkat pendidikan (X1). Dalam penelitian ini akan menggunakan salah satu dari indikator pendidikan yang ada, yaitu : Rata-rata Lama Sekolah (RLS). RLS adalah total jumlah penduduk usia 15 tahun keatas dalam menjalani pendidikan formal yang telah di selesaikan di Provinsi Jambi periode 2004-2014.

c. Kesehatan (X2). Dalam bidang kesehatan ada beberapa indikator yang dapat digunakan dalam mengukur tingkat kesejahteraan masyarakat dari bidang kesehatan yaitu Angka Kematian Bayi, Angka Kematian Ibu melahirkan, Gizi buruk dan Angka Harapan Hidup. Akan tetapi data kesehatan yang akan digunakan dalam penelitian ini adalah data Angka Harapan Hidup (AHH) Provinsi Jambi.

Penelitian ini dimungkinkan memakai regresi linear berganda (Multiple Regression Analaysisis), adalah alat statistik untuk mengetahui pengaruh beberapa variabel bebas terhadap varibel terikat. Sedangkan alasan memakai regresi linear berganda dalam penelitian ini adalah menspesifikan hubungan kausal antara varibel-varibel teramati.

Bentuk umum persamaan regresi linier berganda dengan menggunakan 2 varibel bebas adalah sebagai berikut :

$\mathrm{Y}=\alpha+\beta_{1} \operatorname{LnX}_{1+} \beta_{2} \operatorname{Ln} \mathrm{X}_{2+} \mathrm{e}$ ( Farhan, 2013)

Dimana :

$\mathrm{Y}=$ kemiskinan

$\alpha=$ Konstanta

$\mathrm{X}_{1}=$ Tingkat pendidikan

$\mathrm{X}_{2}=$ Kesehatan

$\mathrm{e}=$ Standar error 
Sehubungan dengan perbedaan satuan yang digunakan dalam penelitian ini, maka digunakan regresi berganda dengan bentuk semi-natural logaritma sebagai berikut :

$$
\mathrm{Y}=\alpha+\beta_{1} \operatorname{LnX}_{1+} \beta_{2} \operatorname{Ln} \mathrm{X}_{2+} \mathrm{e}
$$

Kemudian untuk keperluan pengujian kelayakan model pada analisis regresi berganda maka diperlukan inferensi-inferensi statistik sebagai berikut :

\section{Koefisien Korelasi (R)}

Analisis korelasi bertujuan untuk melihat tingkat keeratan hubungan linier antara dua buah variabel. Tingkat keeratan hubungan tersebut ditunjukkan dengan suatu besaran yang disebut koefisien korelasi $0<\mathrm{R}<1$ yang berarti jika nilai $\mathrm{R}$ mendekati 0 berarti hubungan kedua buah variabel kurang kuat, dan jika nilai $\mathrm{R}$ mendekati 1 menunjukkan semakin besarnya hubungan kedua buah variabel tersebut. (Farhan, 2013)

\section{Koefisien Determinasi $\left(\mathbf{R}^{2}\right)$}

Koefisien determinasi dilakukan untuk melihat kekuatan variabel bebas yang dapat menjelaskan variabel terikat. Koefisien Determinasi $\left(\mathrm{R}^{2}\right)$ dilakukan untuk mengukur besarnya proporsi variasi-variasi variabel terikat (dependent variabel) yang dapat dijelaskan oleh variabel bebasnya (independent variabel).

Sifatnya yang dimiliki koefisien determinasi adalah

1. Nilai $\mathrm{R}^{2}$ selalu positif karena merupakan nisbah dari jumlah kuadrat.

2. Nilai $0<\mathrm{R}^{2}<1$

$\mathrm{R}^{2}<0$, garis regresi yang terbentuk tidak tepat untuk meramalkan variabel dependen

$\mathrm{R}^{2}<1$, garis regresi yang terbentuk dapat meramlakn variabel dependen secara sempurna

Dalam pengujian regresi, ada dua pengujian yang dilakukan untuk mengetahui signifikan dari variabel bebas, yaitu pengujian secara serentak (Uji- F) dan secara individu/parsial (Uji-t)

\section{HASIL DAN PEMBAHASAN}

Diskripsi Data Perkembangan Kemiskinan, Tingkat Pendidikan, dan Kesehatan di Provinsi Jambi.

Perkembangan kemiskinan di Provinsi Jambi jika dilihat dari Tabel 1 dibawah ini persentasenya pada periode 2004-2014 mengalami penurunan. 


\section{Tabel 1a. Jumlah Penduduk Miskin dan Persentase Kemiskinan di Provinsi Jambi Tahun 2004-2014}

\begin{tabular}{|c|c|c|c|c|}
\hline Tahun & $\begin{array}{c}\text { Jumlah } \\
\text { Penduduk } \\
\text { Miskin (000) } \\
\text { Jiwa }\end{array}$ & $\begin{array}{c}\text { Persentase } \\
\text { Penduduk } \\
\text { Miskin (\%) }\end{array}$ & $\begin{array}{c}\text { Perkembangan } \\
\mathbf{( \% )}\end{array}$ & $\begin{array}{c}\text { Garis } \\
\text { Kemiskinan } \\
\text { (Rp) }\end{array}$ \\
\hline 2004 & 325,1 & 12,58 & - & 125.065 \\
\hline 2005 & 317,8 & 11,96 & $-4,93$ & 141.157 \\
\hline 2006 & 304,6 & 11,35 & $-5,10$ & 175.959 \\
\hline 2007 & 281,9 & 9,92 & $-12,60$ & 172.349 \\
\hline 2008 & 261,2 & 9,37 & $-5,54$ & 182.229 \\
\hline 2009 & 245 & 8,64 & $-7,79$ & 199.632 \\
\hline 2010 & 260,4 & 8,42 & $-2,55$ & 216.187 \\
\hline 2011 & 251,8 & 7,88 & $-6,41$ & 242.272 \\
\hline 2012 & 270,1 & 8,45 & 7,23 & 272.267 \\
\hline 2013 & 277,7 & 8,37 & $-0,95$ & 307.803 \\
\hline 2014 & 281,7 & 8,42 & 0,60 & 329.181 \\
\hline Rata-rata & $\mathbf{2 7 9 , 7 5}$ & $\mathbf{9 , 5 8}$ & $\mathbf{- 3 , 4 9}$ & $\mathbf{2 1 4 . 9 1 8 , 2 7}$ \\
\hline
\end{tabular}

Sumber BPS Provinsi Jambi, 2014

Perkembangan jumlah penduduk miskin di Kabupaten/Kota dalam Provinsi Jambi pada tahun 2014 dapat dilihat pada Tabel 1b, dimana di Kota Jambi yaitu sebanyak 51,3 ribu jiwa dengan persentase 18,21 persen. Tanjung Jabung Barat Sebanyak 35,9 ribu jiwa dengan persentase 12, 74 persen dan Merangin 33,2 ribu jiwa dengan persentase 11,79 persen. Ketiga Kabupaten/kota tersebut merupakan penyumbang angka kemiskinan terbesar di Provinsi Jambi yaitu sebesar 64,15 persen. Dan penyebaran penduduk miskin terendah terdapat di Kota Sungai Penuh sebesar 2,8 ribu jiwa atau hanya 0,99 persen dari total angka kemiskinan di Provinsi Jambi. Dan sebanyak 35,85 persen disumbang oleh Kabupaten /Kota lain di Provinsi Jambi. Dari tabel dibawah ini terlihat jelas bahwa Kota Jambi penyumbang angka kemiskinan terbesar di Provinsi Jambi, hal ini disebabkan oleh penyebaran penduduk di Kota Jambi lebih besar dari penyebaran penduduk diKabupaten/Kota lain di Provinsi Jambi.

Tabel 1b. Jumlah Penduduk Miskin Dan Penyumbang Angka Kemiskinan Menurut Kabupaten/Kota di Provinsi Jambi Tahun 2014

\begin{tabular}{|l|c|c|}
\hline \multicolumn{1}{|c|}{ Kabupaten/Kota } & $\begin{array}{c}\text { Kemiskinan } \\
(\mathbf{0 0 0 )} \text { Jiwa }\end{array}$ & Penyumbang (\%) \\
\hline Kerinci & 17,3 & \\
\hline Merangin & 33,2 & 11,79 \\
\hline Sarolangun & 28,2 & 10,01 \\
\hline Batanghari & 26,5 & 9,41 \\
\hline Muaro Jambi & 17,5 & 6,21 \\
\hline Tanjung Jabung Timu & 28,5 & 10,12 \\
\hline Tanjung Jabung Barat & 35,9 & 12,74 \\
\hline
\end{tabular}




\begin{tabular}{|l|c|c|}
\hline Tebo & 23,1 & 8,20 \\
\hline Bungo & 17,4 & 6,18 \\
\hline Kota Jambi & 51,3 & 18,21 \\
\hline Sungai Penuh & 2,8 & 0,99 \\
\hline Provinsi Jambi & $\mathbf{2 8 1 , 7}$ & $\mathbf{1 0 0}$ \\
\hline
\end{tabular}

Sumber BPS Provinsi Jambi, 2014

Pendidikan jika dilihat dari Tabel 2a dan Tabel 2b Perkembangan Rata-rata Lama Sekolah (RLS) di Provinsi Jambi, dimana pada akhir 2014 mengalami perbaikan dengan perkembangan 2,41 persen. Jika dilihat selama periode 2004-2014 RLS menunjukkan peningkatan dengan rata-rata 7,8 per tahun dan perkembangan tertinggi pada tahun 2011 sebesar 3,85 persen dan pada akhir 2014 RLS Provinsi Jambi sebesar 8,5 tahun.

RLS di Provinsi Jambi pada tahun 2014 jika dibandingkan dengan RLS Nasional masih tergolong tinggi, dimana RLS Nasional sebesar 7,6 tahun sementara RLS Provinsi Jambi sebesar 8,5 tahun. Dan jika dibandingkan dengan Provinsi lain di Indonesia, RLS Provinsi Jambi tergolong baik karena masih dalam kisaran 8 tahun. Artinya rata-rata penduduk di Provinsi Jambi mengenyam pendidikan hanya batas kelas 2 semester 1 semester 1 SMP.

Tabel 2a. Rata- rata Lama Sekolah (RLS) Provinsi Jambi Tahun 2004-2014

\begin{tabular}{|c|c|c|}
\hline Tahun & RLS (tahun) & Perkembangan (\%) \\
\hline 2004 & 7,4 & - \\
\hline 2005 & 7,5 & 1,35 \\
\hline 2006 & 7,6 & 1,33 \\
\hline 2007 & 7,6 & 0 \\
\hline 2008 & 7,6 & 0 \\
\hline 2009 & 7,7 & 1,32 \\
\hline 2010 & 7,8 & 1,30 \\
\hline 2011 & 8,1 & 3,85 \\
\hline 2012 & 8,2 & 1,23 \\
\hline 2013 & 8,3 & 1,22 \\
\hline 2014 & 8,5 & 2,41 \\
\hline Rata-rata & $\mathbf{7 , 8}$ & $\mathbf{1 , 2 7}$ \\
\hline
\end{tabular}

Sumber BPS Provinsi Jambi, 2014

Secara umum kondisi pendidikan jika dilihat dari perkembangan Rata-rata Lama Sekolah (RLS) di Provinsi Jambi pada akhir 2014 mengalami perbaikan dengan perkembangan 2,41 persen. Jika dilihat selama periode 2004-2014 RLS menunjukkan peningkatan dengan rata-rata 7,8 per tahun dan perkembangan tertinggi pada tahun 2011 sebesar 3,85 persen dan pada akhir 2014 RLS Provinsi Jambi sebesar 8,5 tahun. 
RLS di Provinsi Jambi pada tahun 2014 jika dibandingkan dengan RLS Nasional masih tergolong tinggi, RLS Nasional mencapai angka 7,6 tahun sementara RLS Provinsi Jambi sebesar 8,5 tahun. Dan jika dibandingkan dengan Provinsi lain di Indonesia, RLS Provinsi Jambi tergolong baik karena masih dalam kisaran 8 tahun. Artinya rata-rata penduduk di Provinsi Jambi mengenyam pendidikan hanya batas kelas 2 semester 1 semester 1 SMP.

Tabel 2b. Perkembangan Rata-rata Lama Sekolah (RLS) Menurut Kabupaten/Kota Provinsi Jambi Tahun 2014

\begin{tabular}{|l|c|c|}
\hline Kabupaten/Kota & RLS ( Tahun) & Perkembangan (\%) \\
\hline Kerinci & 8,5 & 1,10 \\
\hline Merangin & 7,8 & 1,24 \\
\hline Sarolangun & 7,7 & 1,83 \\
\hline Batanghari & 8,1 & 0,80 \\
\hline Muara Jambi & 8,3 & 1,86 \\
\hline TanjungJabungTimur & 6,6 & 0,69 \\
\hline Tanjung Jabung Barat & 7,8 & 0,41 \\
\hline Tebo & 7,7 & 1,79 \\
\hline Bungo & 8,4 & 1,20 \\
\hline Kota Jambi & 11,9 & 0,73 \\
\hline Kota Sungai Penuh & 10,7 & 1,28 \\
\hline Provinsi Jambi & $\mathbf{8 , 5}$ & $\mathbf{1 , 4 6}$ \\
\hline
\end{tabular}

Sumber BPS Provinsi Jambi, 2014

Perkembangan derajat kesehatan penduduk Provinsi Jambi selama periode 2004-2014 dapat dilihat pada Tabel 3 Perkembangan AHH Provinsi periode 2004-2014. Angka Harapan Hidup (AHH) di Provinsi Jambi sejalan dengan perkembangan perbaikan kondisi AHH secara Nasional yang cenderung terus membaik.

Perkembangan AHH Provinsi dalam periode penelitian mengalami peningkatan setiap tahunnya dengan tingkat rata-rata 68,9 tahun dengan rata-rata perkembangan sebesar 0,34 persen sejalan hal ini dengan perkembangan AHH secara Nasional. Angka Harapan Hidup terendah pada tahun 2004 yaitu 67,6 tahun. Angka Harapan Hidup tertinggi berada pada tahun 2014 yaitu 70,2 tahun dengan perkembangan 0,85 persen. Artinya setiap bayi yang lahir hidup mereka memiliki rata-rata perkiraan angka harapan hidup adalah 70 tahun.

Angka Harapan Hidup yang selalu meningkat setiap tahunnya karena semakin meningkatnya pelayanan kesehatan di Provinsi Jambi. Dan dengan adanya Program 
Pemerintah BPJS yang awal berdirinya 1 Januari 2014 di Propinsi Jambi sangat membantu masyarakat Provinsi Jambi dalam meningkatkan kesehatannya.

Berdasarkan tabel diatas Angka Harapan Hidup tahun 2014 tertinggi di Kota Jambi dengan perkembangan 0,18 persen atau 73,3 tahun. Dan Angka Harapan Hidup terendah berada di Tanjung Jabung Timur 66,2 tahun dengan perkembangan 0,44 persen.

Tabel 3a. Perkembangan Angka Harapan Hidup (AHH) Menurut Kabupaten/Kota Provinsi Jambi Tahun 2014

\begin{tabular}{|l|c|c|}
\hline \multicolumn{1}{|c|}{ Kabupaten/Kota } & AHH(tahun) & Perkembangan (\%) \\
\hline Kerinci & 70 & 0,20 \\
\hline Merangin & 71,9 & 0,37 \\
\hline Sarolangun & 69,7 & 0,30 \\
\hline Batanghari & 70,6 & 0,34 \\
\hline Muara Jambi & 71,6 & 0,21 \\
\hline Tanjung JabungTimur & 66,2 & 0,44 \\
\hline Tanjung Jabung Barat & 68,4 & 0,24 \\
\hline Tebo & 70,6 & 0,35 \\
\hline Bungo & 67,6 & 0,51 \\
\hline Kota Jambi & 73,3 & 0,18 \\
\hline Kota Sungai Penuh & 72,3 & 0,10 \\
\hline Provinsi Jambi & $\mathbf{7 0 , 2 0}$ & $\mathbf{0 , 2 4}$ \\
\hline
\end{tabular}

Sumber BPS Provinsi Jambi, 2014

\section{Pengaruh Tingkat Pendidikan, Kesehatan Terhadap Kemiskinan di ProvinsiJambi}

Untuk mengetahui tingkat pendidikan $\left(\mathrm{X}_{1}\right)$ dan $\left(\mathrm{X}_{2}\right)$ terhadap kemiskinan $(\mathrm{Y})$ di Provinsi Jambi Maka dilakukan dengan analisis regresi berganda dengan -menggunakan program SPSS 20.

$$
Y=689,168+5,333 \operatorname{Ln} X_{1}-163,121 \operatorname{Ln}+e
$$

Nilai Konstanta $\alpha=689,168$ dapat diartikan bahwa jika tingkat pendidikan dan Kesehatan konstan maka kemiskinan akan naik sebesar 689,168 orang. Nilai Koefisien $\left(\beta_{1}\right)=$ 5,333 maka dapat diartikan bahwa jika tingkat pendidikan naik $1 \%$ maka kemiskinan akan naik sebesar 5,333 orang, Nilai Koefisien $\left(\beta_{2}\right)=--163,121$ dapat diartikan bahwa jika kesehatan naik $1 \%$ maka kemiskinan akan turun sebesar 163,121 orang.

\subsubsection{Koefisien Korelasi (R)}

Analisis korelasi bertujuan untuk melihat tingkat keeratan hubungan linier antara dua buah variabel. Tingkat keeratan hubungan tersebut ditunjukkan dengan suatu besaran yang disebut koefisien korelasi $0<\mathrm{R}<1$ yang berarti jika nilai $\mathrm{R}$ mendekati 0 berarti hubungan 
kedua variabel kurang kuat, dan jika nilai $\mathrm{R}$ mendekati 1 menunjukkan semakin besarnya hubungan kedua variabel tersebut.

Dari hasil perhitungan secara statistik dengan menggunakan SPSS 20 diperoleh nilai Koefisien Korelasi (R) sebesar 0,829 yang artinya hubungan kedua variabel tergolong kuat karena R mendekati 1.

\section{Koefisien Determinasi $\left(\mathbf{R}^{2}\right)$}

\begin{tabular}{|l|r|r|r|r|}
\hline Model & \multicolumn{1}{|c|}{$\mathrm{R}$} & R Square & \multicolumn{1}{c|}{$\begin{array}{c}\text { Adjusted } \mathrm{R} \\
\text { Square }\end{array}$} & $\begin{array}{l}\text { Std. Error of the } \\
\text { Estimate }\end{array}$ \\
\hline 1 & $.839^{\mathrm{a}}$ & .703 & .629 & 1.01376 \\
\hline
\end{tabular}

Uji Koefisien Determinasi bertujuan untuk menentukan proporsi atau persentase total variasi dalam variable terikat yang diterangkan oleh variable bebas. Hasil perhitungan $\mathrm{R}$ square dapat dilihat pada output model summary. Pada kolom R square diketahui hasil perhitungan secara statistik dengan menggunakan SPSS 20 diperoleh nilai koefisien determinasi $\mathrm{R}^{2}$ sebesar 0,703 atau 70,30 \%. Artinya kemampuan variabel bebas yang terdiri dari tingkat pendidikan (RLS), kesehatan (AHH) mampu menjelaskan variabel terikat (kemiskinan) yaitu 70,30\% sedangkan sisanya 29,70\% ditentukan oleh faktor lain yang tidak dijadikan variabel didalam penelitian ini.

\section{Pengujian Hipotesis}

\section{Pengujian Hipotesis secara Bersama-sama (Uji-F)}

Uji F- statistik (Overal Test) ini dimaksudkan untuk mengetahui signifikan statistik koefisien regresi secara bersama-sama dengan membandingkan nilai F-hitung dengan F-tabel yang dalam penelitian ini menggunakan tingkat kepercayaan $95 \%$ atau $\alpha=5 \%$.

Dari hasil perhitungan diperoleh nilai F-hitung dari ANNOVA sebesar 9,810 dengan $\alpha=5 \%$ dan di ketahui nilai F-tabel sebesar 3,44. Itu artinya nilai F-hitung $>$ F- tabel maka Ho ditolak dan Ha diterima. Ini berarti secara bersama-sama variabel tingkat pendidikan ( $\left.\mathrm{X}_{1}\right)$ kesehatan $\left(\mathrm{X}_{2}\right)$ berpengaruh signifikan terhadap variabel tingkat kemiskinan $(\mathrm{Y})$.

\section{Pengujian Hipotesis secara Parsial (Uji-t)}

Uji t-statistik (Parsial Test) ini dimaksudkan untuk mengetahui signifikan regresi secara parsial dengan membandingkan nilai t-hitung dengan t-tabel yang dalam penelitian ini menggunakan kepercayaan $95 \%$ atau $\alpha=5 \%$ dan $(\mathrm{d}-\mathrm{f})=10$. 
Dari hasil perhitungan diketahui bahwa :

1. Tingkat Pendidikan $\left(\mathrm{X}_{1}\right)$. Dari hasil perhitungan diketahui nilai t-hitung pada variabel tingkat pendidikan $\left(\mathrm{X}_{1}\right)$ sebesar 0,273 dengan $\mathrm{df}=10$ dan menggunakan uji dua sisi dengan tingkat kepercayaan $95 \%$ atau $\alpha=5 \%$. Artinya nilai t-hitung $<$ t-probabilitas, maka Ho diterima dan Ha ditolak. Ini berarti pada penelitian ini variabel tingkat pendidikan secara parsial tidak berpengaruh signifikan terhadap kemiskinan di Provinsi Jambi.

2. Kesehatan $\left(\mathrm{X}_{2}\right)$. Dari hasil perhitungan diketahui nilai t-hitung pada variabel kesehatan $\left(\mathrm{X}_{2}\right)$ sebesar 1,797 dengan $\mathrm{df}=10$ dan menggunakan uji dua sisi dengan tingkat kepercayaan $95 \%$ atau $\alpha=5 \%$. Artinya nilai t-hitung $>$ t-probabilitas, maka Ho ditolak dan Ha diterima. Ini berarti pada penelitian ini variabel kesehatan secara parsial berpengaruh signifikan terhadap kemiskinan di Provinsi Jambi.

\section{Penjelasan Secara Empiris}

Dari hasil estimasi model diketahui bahwa variabel tingkat pendidikan (RLS) dan kesehatan $(\mathrm{AHH})$ secara bersama-sama atau uji $\mathrm{F}$ dapat mempengaruhi kemiskinan secara signifikan di Provinsi Jambi dengan taraf signifikan 95\% atau $\alpha 5 \%$. Akan tetapi tidak dengan pengujian secara parsial atau individu.

Dari hasil perhitungan secara uji-t atau secara individu diketahui bahwa pada tingkat keyakinan $95 \%$ atau $\alpha=5 \%$ hanya tingkat Kesehatan yang berpengaruh signifikan terhadap kemiskinan di Provinsi Jambi. Sedangkan Pendidikan berpengaruh tidak signifikan terhadap kemiskinan.

Temuan empiris ini telah juga ditemukan oleh para peneliti sebelumnya, seperti penelitian yang dilakukan oleh Ali Fahmi (2004) mengungkapkan Kesehatan Faktor Penting dalam Pembangunan, senada dengan itu Herri Faisal (2013) menyimpulkan bahwa tingkat pendidikan dan kesehatan berpengaruh terhadap produktivitas dan kemiskinan di Provinsi Kalimantan Barat dengan menggunakan model regresi teknik Last Square Dummy variabel (LSDV) Begitujuha penelitian Darma Rika S dkk (2012) menyimpulkan bahwa tingkat pendidikan dan pendapatan perkapita berpengaruh negatif dan signifikan terhadap kemiskinan di DKI Jakarta sedangkan pengangguran berpengaruh positif dan signifikan terhadap kemiskinan di DKI Jakarta. 
Hasil penelitian ini sama dengan penelitian sebelumnya dimana tingkat pendidikan berpengaruh negatif sedangkan kesehatan berpengaruh positif. Secara bersama-sama tingkat pendidikan dan kesehatan berpengaruh signifikan sedangkan secara uji-t atau parsial hanya tingkat kesehatan yang berpengaruh signifikan sedangkan pendidikan berpengaruh tidak signifikan terhadap kemiskinan di Provinsi jambi.

Hal ini disebabkan oleh pendidikan yang belum mengarah kepada keterampilan sehingga walaupun tingkat pendidikan realtif tinggi tapi belum tentu dapat bekerja sehingga menjadi Penggangguran, maka akan semakin miskin.

Hasil penelitian ini tidak sesuai dengan teori lingkaran kemiskinan yang apabila produktivitas rendah maka akan mendapatkan pengahasilan yang rendah pula apabila penghasilan rendah maka tidak dapat menabung sehingga tidak ada rangsangan untuk berinvestasi. Untuk itulah perlunya memperbaiki sumber daya manusia agar produkvitas manusia meningkat. Kenyataannya dapat dilihat dengan melakukan investasi pendidikan akan mampu meningkatkan pengetahuan dan ber keterampilan. Semakin tinggi tingkat pendidikan seseorang jika tidak diikuti oleh keahlian atau ketampilan tidak akan mampu mendorong dan meningkatkan produktivitas kerjanya.

\section{Kesimpulan dan Saran}

\section{Kesimpulan}

Dalam periode penelitian ini menunjukkan bahwa kemiskinan Provinsi Jambi mengalami penurunan dengan tingkat rata-rata sebesar 3,49 persen, Perkembangan tingkat pendidikan yang dilihat dari RLS rata-rata 1,27 persen pertahun danPerkembangan kesehatan dilihat dari $\mathrm{AHH}$ juga mengalami peningkatan setiap tahunnya dengan rata-rata sebesar 0,34 persen pertahun.

Pengaruh tingkat pendidikan terhadap kemiskinan menunjukkan pola hubungan yang positif tapi tidak signifikan terhadap kemiskinan dengan nilai koefisien regresi sebesar 5,333. Artinya meningkatnya tingkat pendidikan maka akan meningkatkan angka kemiskinan sebesar 5,333.Hal ini sebabkan pendidikan yang belum diikuti oleh tingkat keterampilan sehingga tidak produktif.

Kesehatan berpengaruh negative tapi signifikan terhadap kemiskinan dengan nilai koefisien regresi kesehatan adalah $(-163,121)$. Artinya semakin meningkat kesehatan maka kemiskinan akan menurun sebesar 163,121. 
Hal ini disebabkan jika tingkat kesehatan meningkat, maka tingkat produktivitasnya tinggi sehingga menyebabkan tingkat Pendapatan meningkat.

\section{Saran}

Saran untuk tingkat pendidikan berpengaruh tidak signifikan terhadap kemiskinan, namun dikarekan tingkat pendidikan di Provinsi Jambi masih belum menyentuh kepada keterampian terutama ketarampilan hidup (life Skilss), maka di harapkan untuk memperbaiki tingkat pendidikan dan keterampilan atau (life skills) supaya dapat mendorong peningkatan SDM yang pada akhirnya akan meningkatan produktivitas.

Tingkat kesehatan terjadi hubungan negatif tapi signifikan terhadap kemiskinan di Provinsi Jambi, maka diharapkan pemerintah lebih memperhatikan program kesehtan sebagai modal tahan lama dalam terori ekonomi.

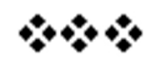

\section{Daftar Pustaka}

Adisasmita, Raharjo, 2013. Teori-teori pembangunan ekonomi, pertumbuhan ekonomi dan pertumbuhan wilayah, Graha ilmu, Yogyakarta

Ali Fahmi. (2004) Kesehatan Faktor Penting dalam Pembangunan. Jurnal Ilmiah Universitas Batanghari. ISS-1411-8939.

Astri Winarti."Analisis pengaruh Pengeluaran Pemerintah di Bidang Pendidikan, Kemskinan, dan PDRB terhadap Indeks Pembangunan Manusia Indonesia Periode 1992-2012."Skripsi Fakultas Ekonomi Universitas Diponegoro. Semarang 2014

Badan Pusat Statistik. 2014.Angka Harapan Hidup Penduduk Provinsi Jambi Tahun 20042014.Jambi : Badan Statistik Provinsi Jambi.

Badan Pusat Statistik. 2014. Jumlah Penduduk Miskin Provinsi Jambi Tahun 20042014.Jambi: Badan Pusat Statistik Provinsi Jambi.

Badan Pusat Statistik. 2014. Rata Lama Sekolah Penduduk Provinsi Jambi Tahun 20042014.Jambi : Badan Statistik Provinsi Jambi.

Chiristina, Usmaliaanti. Analisis Pngaruh Tingkat Kemiskinan, Pengeluaran Pemeintah sektor Pendidikan dan Kesehatan terhadap Indeks Pembangunan Manusia di Provinsi Jawa Tengan Tahun 2007-2009. Skripsi Fakultas Ekonomi Universitas Diponegoro Semarang. 2011 
Cholini, Fakhul Mufid, M. Pudji Hardjo. "Analisis Pengaruh PDRB, Pengangguran, dan IPM terhadap jumlah penduduk miskin (studi kasus 33 provinsi di Indonesia”. Jurnal Ilmiah Mahasiswa Fakultas Ekonomi Pembangunan, Universitas Brawijaya. Vol 2 No 1. Semester ganjil 2013/2014. Diakses 29 Desember 2014

Darma Rika S, Munawaroh, Dita Puruwita, 2012. "Pengaruh Tingkat Pendidikan, Pendapatan per kapita, dan Pengangguran Terhadap Kemiskinan di DKI Jakarta”. Jurnal Ilmiah Fakultas Ekonomi, Universitas Negeri Jakarta, Volume X, Nomor 2, Agustus 2012. Econosains.Com

Faisal, Herry, 2013. “Pengaruh tingkat pendidikan dan tingkat kesehatan, terhadap produktivitas dan jumlah penduduk miskin di provinsi Kalimantan Barat”. Tesis, Fakultas Ekonomi, Universitas Tanjung Pura, Pontianak.

Fransciari, Purnawiyanti Septina, 2012. “Analisis Hubungan IPM, Kapasitas Fiskal, dan Korupsi terhadap Kemiskinan di Indonesia”. Skripsi, Fakultas Ekonomi dan Bisnis, Universitas Diponegoro. Semarang. Eprints.undip.ac.id

Jonathan Sarwono. 2007. Panduan Cepat dan Mudah SPSS 14, CV. Andi Offset, Yogyakarta.

Darma Rika S, Munawaroh, Dita Puruwita, 2012. "Pengaruh Tingkat Pendidikan, Pendapatan per kapita, dan Pengangguran Terhadap Kemiskinan di DKI Jakarta”. Jurnal Ilmiah Fakultas Ekonomi, Universitas Negeri Jakarta, Volume X, Nomor 2, Agustus 2012. Econosains.Com

Raditya Widyasoro Astri Winarti."Analisis pengaruh Pendidikan, Kesehatan dan tingkat kerja wanita terhadap Kemiskinan di Kabupaten Gersik (studi Kasus Tahun 2008-2012). Skripsi Fakultas Ekonomi Universitas Brawijaya. 2014

Adit Agus, 2010. “Analisis Faktor-faktor yang mempengaruhi Tingkat Kemiskinan”. Skripsi, Fakultas Ekonomi, Universitas Diponegoro, Semarang.

Qudratullah, Muhammad Farhan. 2012. Analisis Regresi Terapan. Penerbit Andi. Yogyakarta

Triariani, Endang Ernany. 2012. "Analisis pengaruh pertumbuhan ekonomi, jumlah pengangguran, dan IPM terhadap jumlah penduduk miskin di kab. Berau”. Jurnal academic.ac

Utomo, Agung Priyo.2007. "Faktor-kemiskinan secara makro di lima belas provinsi di Indonesia tahun 2007”. Jurnal Organisasi dan Manajemen, vol 6, no 2, September 2010. Lppm.ut.ac.id diakses pada 13 Februari 2015

Yoga Anggit, Ariyanti, dan Fitri, 2012. "Analisis pengaruh PDRB, Pengangguran, Pendidikan, dan Kesehatan terhadap Kemiskinan di Jawa Tengah tahun 2004-2009." Skripsi, Fakultas Ekonomi, Universitas Diponegoro, Diakses pada tanggal 23 Januari 2015 